\title{
GROUND FAILURE ALONG THE NEW RIVER CAUSED BY THE OCTOBER 1979 IMPERIAL VALLEY EARTHQUAKE SEQUENCE
}

\author{
By Thomas H. Heaton, John G. Anderson, and Peter T. German
}

\begin{abstract}
We recognized a number of ground failures along the south bank of the New River north of Brawley, California, following the 15 October 1979 Imperial Valley, California, earthquake sequence. The zone includes a large pond and numerous sand boils, apparently caused by liquefaction, near the Del Rio Country Club. These ground failures, together with failures at the New River bridge west of Brawley and at Wiest Lake, form a discontinuous zone $10 \mathrm{~km}$ long. While this zone appears to coincide with the aftershocks following the 16 October 1979, $M_{L}$ 5.8, Brawley earthquake (the largest aftershock of the Imperial Valley earthquake), a cause and effect relationship cannot be demonstrated. No evidence of tectonic surface faulting could be found.
\end{abstract}

\section{INTRODUCTION}

This report documents earthquake-generated ground disturbance along a $\mathrm{N} 45^{\circ} \mathrm{E}-$ trending zone that appeared during the earthquake sequence that began with the $M_{L}$ 6.6, 15 October 1979 Imperial Valley earthquake. Several of the ground failures in this zone were discovered on 2 November 1979 when we were dismantling a temporary accelerometer array installed to record aftershocks of the 15 October 1979 Imperial Valley earthquake (Anderson and Heaton, 1982). While removing an instrument from the Del Rio Country Club, which lies on the banks of the New River, our attention was drawn to a rather impressive new pond in the river flood plain. This pond was surrounded by numerous sand boils and had evidently been formed by liquefaction. Upon exploring this pond, we discovered a rather obvious extension crack which ran from the perimeter of the pond and then up the river bank. We spent the remaining daylight hours searching along the trend of this crack and found a discontinuous zone of disturbance along the southern bank of the New River from Brawley to Wiest Lake $(10 \mathrm{~km})$.

Several weeks later, Carl Johnson, of the U.S. Geological Survey, discovered that the largest aftershock, or the Brawley earthquake (16 October 1979, $M_{L} 5.8$ ), had an aftershock zone that apparently coincided with the zone of disturbance we had found. Furthermore, accelerograms recovered from the Del Rio Country Club showed clear and impressive evidence of near-field ground motions, which strongly suggests nearby primary faulting (Anderson and Heaton, 1982). This evidence raises the question of whether the disturbances may actually be due to surface faulting along the trace of a previously unmapped fault. Our brief and poorly documented original exploration of the zone of ground disturbance was inadequate to resolve that question. Thus, we returned to the Imperial Valley on 5 March 1980 to conduct a more thorough investigation. Much of the original ground disturbance was still well preserved. This second inspection led us to conclude that the ground disturbance we observed is probably not the surface expression of primary faulting. Youd and Wieczorek (1983) also concluded that secondary ground failure was the probable origin of all the ground disturbances they studied in this area.

In the remainder of this report, we describe the zone of ground disturbance observed along the trend of the New River between Brawley and Wiest Lake. Next, we summarize evidence of Johnson and Hutton (1982) which suggests that the 
Brawley earthquake occurred on a fault that may trend along the New River. Finally, we discuss whether geomorphic features of the new River may be due to faulting.

\section{Ground Disturbance}

Ground disturbances between Brawley and Wiest Lake are confined to a zone which coincides with the $\mathrm{N} 45^{\circ} \mathrm{E}$-trending lineament in seismicity discussed in Johnson and Hutton (1982). The following numbered descriptions refer to numbered locations shown in Figure 1 and begin at the southwest end of the zone of seismicity and ground disturbance.

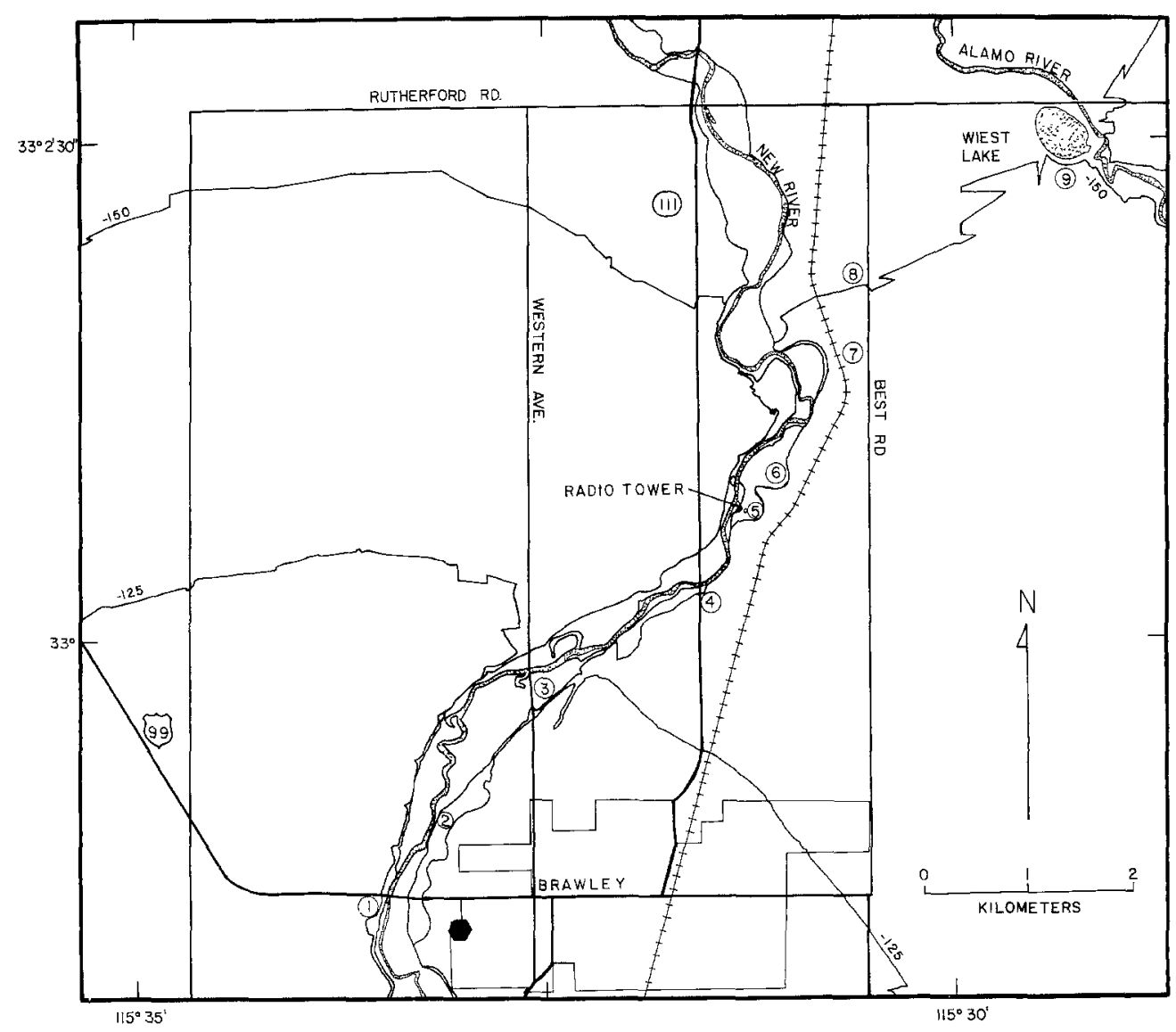

Fig. 1. Index map showing locations of disturbed ground following the Imperial Valley earthquake sequence. Numbered locations are described in the text. Hexagon shows the epicenter of the $M_{L} 5.8$ aftershock. The contour interval is $25 \mathrm{ft}(8 \mathrm{~m})$, and topography related to irrigation systems has been removed.

1. New River-Main Street Bridge. The main street of Brawley is four lanes wide and crosses the New River on twin reinforced-concrete bridges. Although slumping of the foundations of both bridges was responsible for serious damage, we found no evidence of through-going cracks in this area. It appears that these bridges were damaged by the main shock, prior to the $M_{L} 5.8$ Brawley earthquake. Thus, although these bridges sustained serious damage and were located very close to the Brawley earthquake, we do not know whether ground disturbance occurred at this location 
at the time of the Brawley earthquake. A more complete discussion of ground failure in this area is given by Youd and Wieczorek (1982). They also describe extensive liquefaction at "River Park," which is located along the east side of the New River at the southwest edge of Brawley. Although we did not examine this location, it is on the same trend as other disturbances described in this report.

2. New River Valley Northeast of Brawley. We searched the southeast side of the New River valley just northwest of Brawley for any signs of ground cracking. There was no obvious ground rupture or disturbance in this area.

3. Imperial County Dump. Several examples of ground failure were found in the area of the Imperial County Dump. Although no major ground failures could be found along Western Avenue, there was extensive tensional cracking along the top of and parallel to the river bluff in this area. In at least one location, just above Western Avenue, these cracks occurred in sand and silt sedimentary deposits. A paved road runs northeast through the dump for about $500 \mathrm{~m}$, then climbs up the southeast bluff of the New River. N45 ${ }^{\circ}$ E-tending cracks were found in the road where it intersects the river bluff. The cracks were parallel to the river bluff (which is quite straight), and a $1 \mathrm{~cm}$ down-to-the-northwest displacement was measured. However, the cracking did not extend into the thinly-bedded sand and silt in the river bluff beneath the road. It also appeared that the cracking occurred at a cut-fill boundary. Thus, differential settling due to shaking is the probable origin of this cracking.

4. Entrance to the Del Rio Country Club. Small north-south-trending scarps were seen at the top of the river bluff just west of the roadcut off Highway 111 in the southeast river bluff. These scarplets extended several tens of meters and had a total vertical throw of about $30 \mathrm{~cm}$ with the east side downthrown. However, it appeared that Pleistocene silt and clay layers were undisturbed in the east side of the roadcut. Thus, it appears likely that these scarplets were due to localized slumping in the roadcut. To the northeast, the southwest end of a $\mathrm{N} 60^{\circ} \mathrm{E}$-trending concrete culvert which runs along the country club driveway was badly cracked and buckled and appeared to be shortened. Cracks were also found along and parallel to the river bluff along the country club driveway. There was no evidence to suggest that any of these features were the direct result of faulting.

5. Liquefaction Area Adjacent to the KROP Radio Tower. A sizable pond was apparently created when liquefaction occurred in the New River Valley adjacent to the KROP radio transmitter (Figure 2). This pond is one of the most dramatic examples of liquefaction we saw anywhere for the Imperial Valley earthquake sequence. Numerous sand boils around the margin of the pond were still oozing water on 2 November, 2 weeks after the earthquake. A discontinuous zone of extensile cracks was found along about 50 per cent of the perimeter of this pond suggesting that the flood plain had subsided. We estimate the dimension of this pond to be about $50 \times 75 \mathrm{~m}$, with a depth of probably less than $30 \mathrm{~cm}$. A N5 ${ }^{\circ} \mathrm{E}$ trending extensile crack ran from the perimeter of the pond, subparallel to the river bluff, and then up the side of the river bluff (Figure 3). It could not be followed into the golf course which lies on the flat land above the bluff. Ground failure is the most reasonable explanation for these observations.

6. North Boundary of Del Rio Country Club. Northeast-southwest-trending cracks were found in a dirt road along the base of the river bluff on the northeast corner of the golf course. Unfortunately, these cracks were obliterated before we returned on our second visit. It appeared that sedimentary strata were undisturbed in the adjacent river bluff. 
7. Southern Pacific Railroad Tracks. We sighted along the railroad tracks in this area, but no misalignment was observed; however, some disruption of a concrete drainage ditch occurred in this locality. Youd and Wieczorek (1982) also reported minor damage at the Brawley Sewage Treatment Plant on the east side of the New River just south of location 7. They reported that open fissures as wide as $6 \mathrm{~cm}$ passed through the treatment plant.

8. Best Road. Victor Lamanuzzi (U.S. Geological Survey, personal communication) told us that south-trending extensile cracks in soil above a drainage ditch just west of Best Road could be traced for about $10 \mathrm{~m}$ until they disappeared in a plowed field. We searched for these cracks, but found no evidence of ground disturbance here.

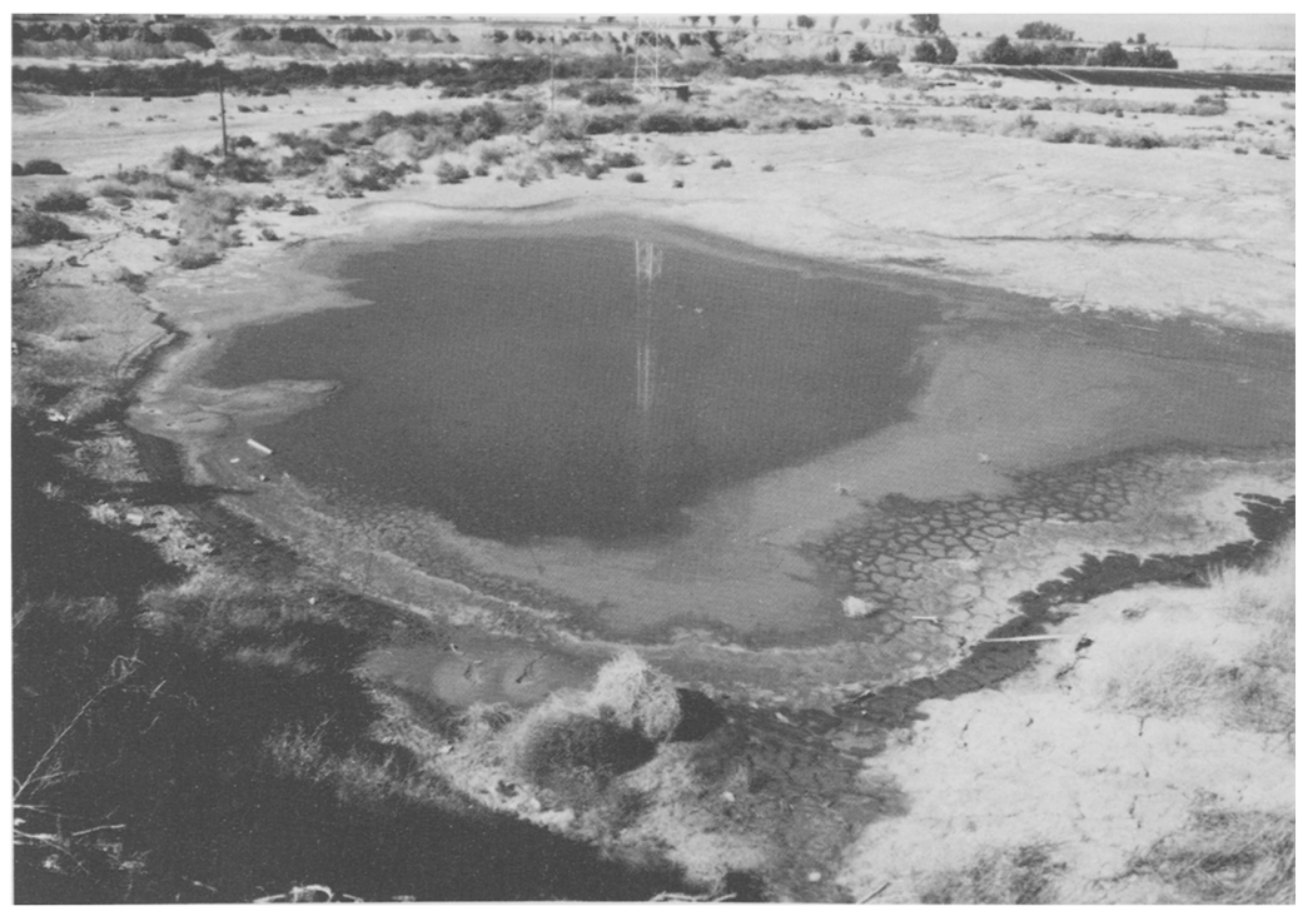

FIG. 2. Pond formed in New River Valley next to the Del Rio Country Club (location 5 on the index map). The pond was apparently formed by liquefaction during the earthquake sequence. Extensile cracks were found along much of the perimeter of the pond, and numerous sand volcanoes were still oozing water 2 weeks after the main shock. View is to the northwest.

9. Wiest Lake. Wiest Lake was an area of fairly extensive liquefaction and ground disturbance with a complex pattern of cracks and a few sand boils. Disruption was most severe in the strip of fill that divides Wiest Lake from the Alamo River to which it was once connected. Cracks trending north-south and northeast-southwest were common in and near the parking lot of Wiest Lake County Park. One northeastsouthwest-trending crack showed $2 \mathrm{~cm}$ of left-lateral displacement where it crossed an asphalt curb and painted lines in the parking lot. Cracks, tending $\mathrm{N} 65^{\circ} \mathrm{W}$ crossed the road just southeast of the lake. There was little evidence of disruption of either the ground or layered sediments along the north and west banks of Wiest Lake. It appears that much of this complex cracking pattern may be explained by a general 


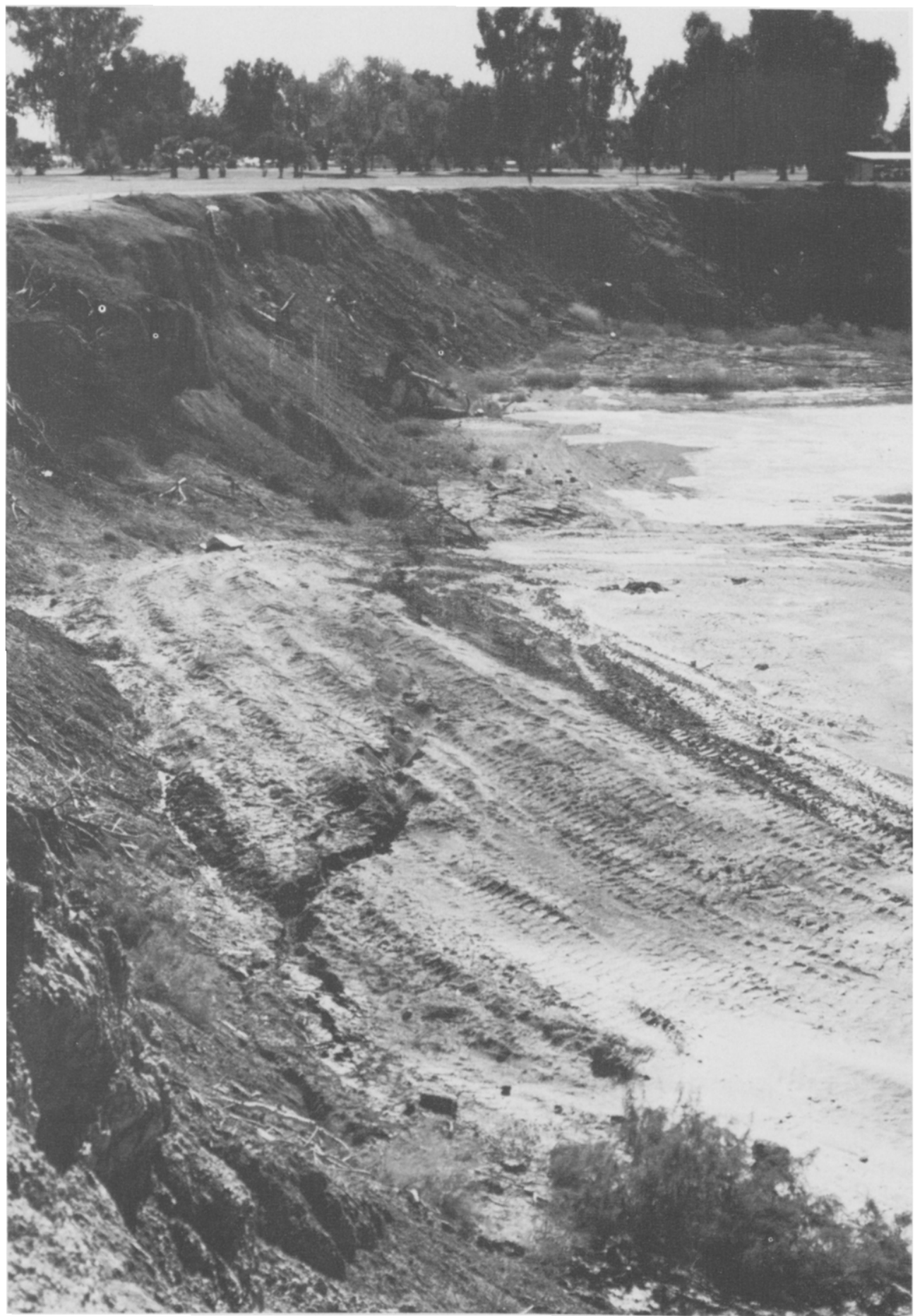

FIG. 3. Linear extension crack at Del Rio Country Club. Crack is subparallel to the river bank and can be seen running obliquely up the bank in the foreground. View is to the south. Liquefaction pond and clubhouse are in the background. 
slumping of the artificial eastern embankment of Wiest Lake toward the northeast and into the Alamo River. The northeast bank of the Alamo River is perpendicular to the northeast-trending seismicity zone and shows a layered sequence of sediments from 3 to $6 \mathrm{~m}$ thick in the river bank; whereas we saw no convincing evidence that these sediments were disrupted, our search was not exhaustive, and a more thorough examination may be warranted. Although surface fault rupture cannot be conclusively ruled out, it appears that the ground disturbance at Wiest Lake was probably due to the failure of weak artificial fill in the Alamo River Valley.

We do not know the precise timing of these soil failures. The Imperial County Department of Parks and Recreation reports that soil failure at Wiest Lake was first noticed in the late afternoon of 15 October, i.e., after the Imperial earthquake, but before the Brawley earthquake. However, Kerry Sieh (Caltech, personal communication) received eyewitness accounts indicating that a large portion of the ground failure at Wiest Lake was associated with the Brawley earthquake.

\section{The 16 October 1979 Brawley Aftershock}

The Imperial Valley earthquake of 15 October 1979 (2316 UTC, $M_{L} 6.6$ ) triggered a series of aftershocks which Johnson and Hutton (1982, Figure 1) mapped for the first 20 days after the main shock. A striking feature of the aftershocks is the way they cluster north of the major zone of surface faulting (as given by Sharp et al., 1982). The largest aftershock $\left(M_{L} 5.8\right)$ in the sequence occurred at 0659 on 16 October and has a preliminary hypocentral solution of $32.978^{\circ} \mathrm{N}$ latitude, $115.550^{\circ} \mathrm{W}$ longitude, and $7 \mathrm{~km}$ depth, which places it beneath the west end of Brawley and well north of the recognized surface faulting of the Imperial Valley earthquake (Figure 4). This solution is slightly different from that given in Johnson and Hutton (1982) because $S$-wave arrival times read from nearby strong-motion accelerograms were used to constrain this solution. The focal mechanism determined by Johnson and Hutton (1982) for this event indicates either right-lateral movement on a vertical $\mathrm{N} 45^{\circ} \mathrm{W}$-trending plane or left-lateral movement on a $\mathrm{N} 45^{\circ} \mathrm{E}$-trending plane. Based on the $\mathrm{N} 45^{\circ} \mathrm{E}$-trending lineament of seismicity which developed after this earthquake, Johnson and Hutton (1982) concluded that the $\mathrm{N} 45^{\circ} \mathrm{E}$-trending plane is most likely the fault plane.

Figure 4 shows aftershock activity in the vicinity of Brawley for the $8 \mathrm{hr}$ between the occurrence of the Imperial Valley main shock and the $M_{L} 5.8$ Brawley earthquake. Figures 5 and 6 show aftershock activity for the same region for 8 and $48 \mathrm{hr}$ after the occurrence of the Brawley earthquake, respectively. Although a clear seismicity trend running along our transect can be seen in the 2 days after the Brawley earthquake (Figure 6), this trend is not obvious in the first $8 \mathrm{hr}$ after it (Figure 5). In fact, given only the first $8 \mathrm{hr}$ of seismicity, either of Johnson and Hutton's (1982) focal planes appears to be be a plausible choice for the New River earthquake. However, the clear development of a northeast-southwest trend in the later aftershocks suggests that a northeast-southwest trending fault is the more reasonable interpretation of the source of this earthquake. Based on the seismicity evidence of Figure 6, the location of the surface trace of this postulated fault is uncertain by 2 to $3 \mathrm{~km}$ perpendicular to its trend. Because the aftershock zone lengthens with time, it is not possible to estimate the rupture length of the main shock.

\section{Discussion}

Ground failures occurred at several localities in the New River. There is also evidence that the $M_{L} 5.8$ Brawley aftershock may have occurred on a fault coincident 
with the trend of the New River. Did the Brawley aftershock cause or contribute to the formation of the ground disturbances we observed?

The timing of the disturbances is both critical and uncertain. Except for the eyewitness account at Wiest Lake, there is no way to demonstrate that they occurred in the Brawley aftershock rather than during the Imperial Valley earthquake. They may have even occurred during other aftershocks, and all of them may not have formed simultaneously. We know that soil fractures occurred at Wiest Lake and the

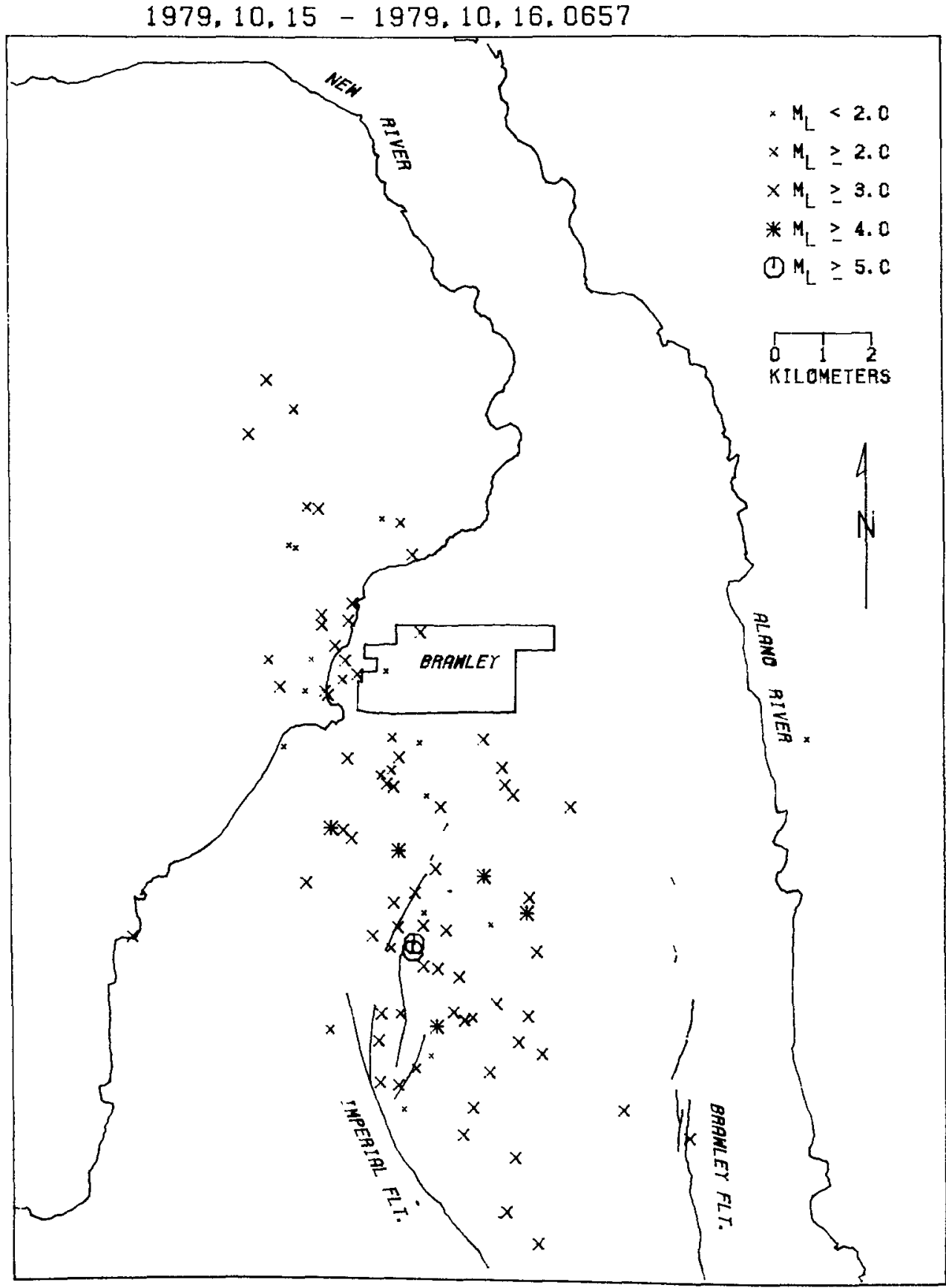

Fig. 4. Aftershocks of the Imperial Valley earthquake in the vicinity of Brawley before the $M_{L} 5.8$ Brawley earthquake. This map shows all "a" and "b" quality locations. 
New River-Main St. Bridge prior to the Brawley aftershock. But we also know that the Brawley aftershock was stronger and more damaging in Brawley than the Imperial Valley earthquake. It is probable that the Brawley aftershock contributed significantly to the disturbances.

Earthquakes of this magnitude commonly have associated ground disturbances;

$1979,10,16,0659-1979,10,16,1459$

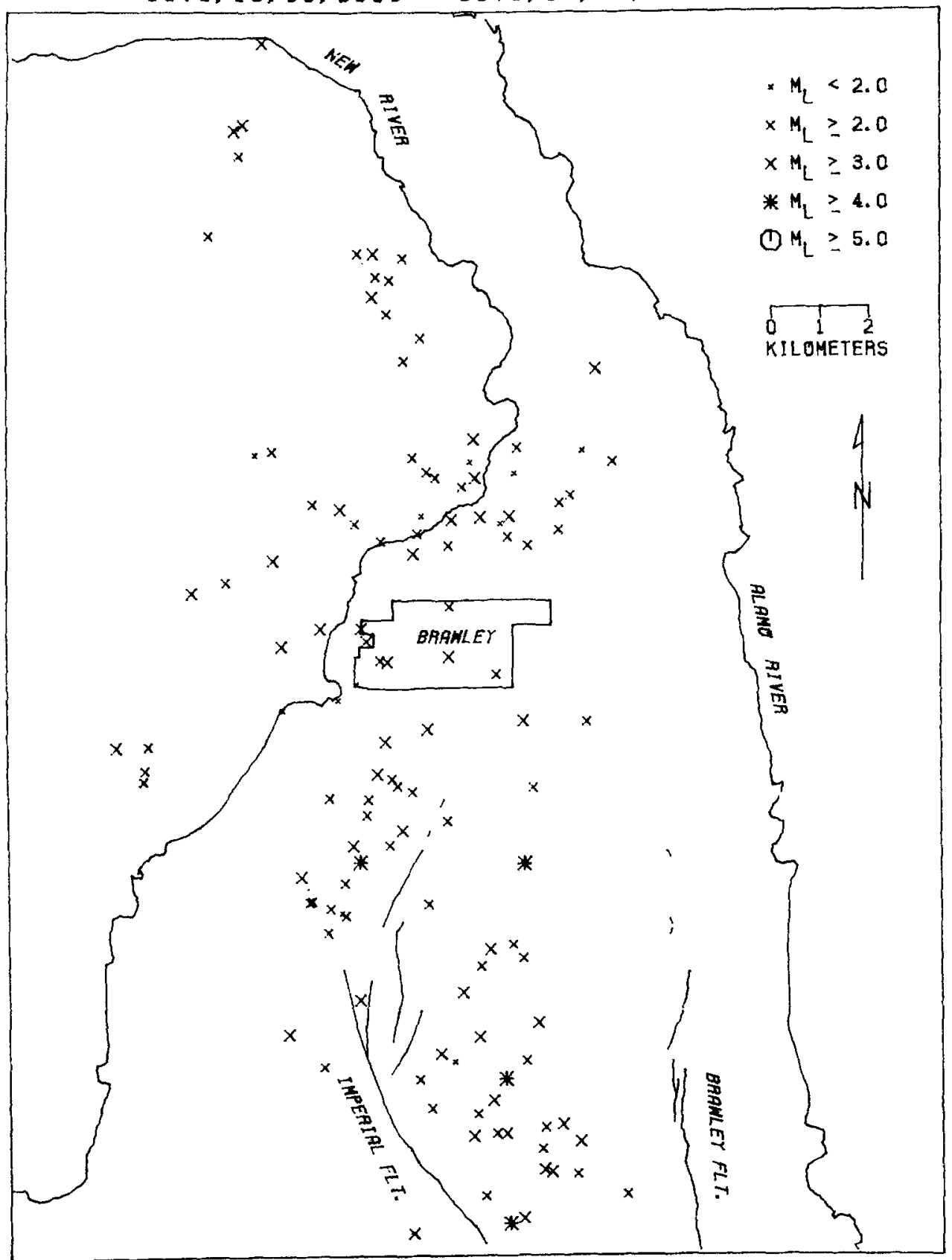

FIG. 5. Aftershocks of the Imperial Valley earthquake in the first $8 \mathrm{hr}$ following the $M_{L} 5.8$ Brawley earthquake. 
being a part of an aftershock sequence should in no way change that expectation. Thus, it is reassuring that we did in fact find surface deformation in the aftershock zone of the Brawley earthquake; the most dramatic and obvious examples occurring at the Del Rio Country Club and at Wiest Lake. It appears that failure and liquefaction of soils in the river valley are the most reasonable explanations for the ground disturbances we found. No clear evidence of faulting of sediments exposed

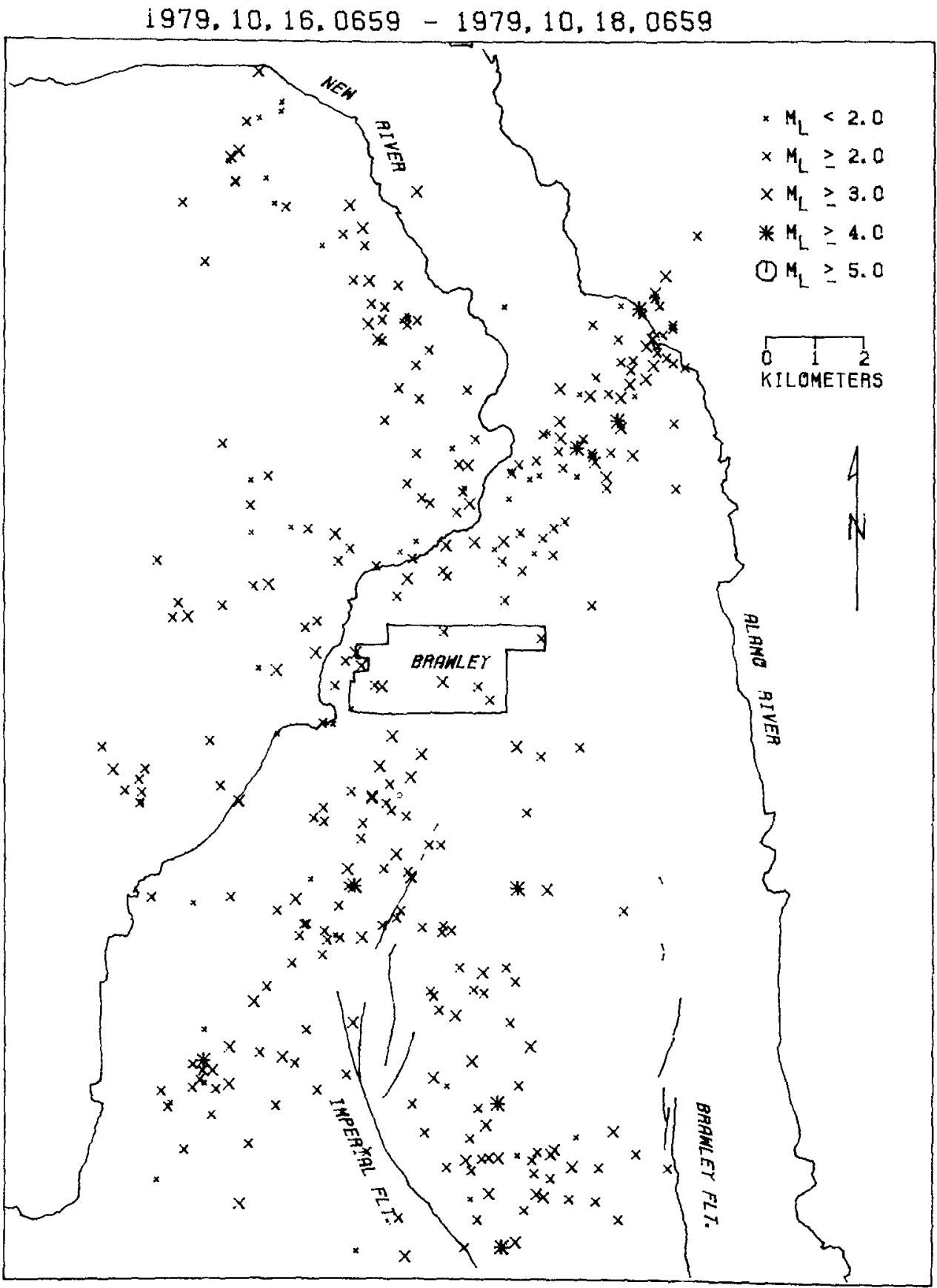

FIG. 6. Aftershocks of the Imperial Valley earthquake in the first $48 \mathrm{hr}$ after the Brawley earthquake. 
in the river bluffs could be found, but our investigations could not be considered to be exhaustive.

Is there a relationship between the trend of the zone of ground disturbance and the causative fault of the Brawley earthquake? Because all the ground disturbances which we found are associated with river banks or with river or fill sediments, their locations do not necessarily indicate the immediate proximity of faulting. It can be argued that the phenomena we observed form a linear zone because the New River itself is nearly linear, with Wiest Lake located coincidentally along the trend. By this argument, a similar linear trend of ground failure may be expected whenever an earthquake anywhere in the Imperial Valley causes strong enough shaking in the vicinity of Brawley.

On the other hand, the location and orientation of the New River north of Brawley may be fault controlled. The New River valley has a linear trend along the aftershock zone. A cross section perpendicular to the New River near Brawley shows that the river channel is cut into a broad but subtle topographic high (e.g., the 125-ft contour in Figure 1). A geothermal field is present along this trend between the New River and Wiest Lake. Because the Imperial and Brawley faults are associated with subtle linear topography, there is reason to be cognizant of other linear physiographic features in the Imperial Valley.

It is important to recognize that the physiography of the New River was dramatically changed by the great floods which occurred in the years 1905 through 1907 when the Colorado River was accidentally diverted northward into the Salton Trough. The present New River valley was formed catastrophically when much of the discharge of the flooding Colorado River flowed down the New River. A gorge $10 \mathrm{~m}$ deep and several hundred meters wide was rapidly cut through the friable Imperial Valley sediments by the rampaging river (Sykes, 1937). Although one might think that this dramatic formation of the gorge is the origin of the New River's name, Sykes (1937) documented the fact that the New River was explored as early as 1851 . It was apparently characterized by a shallow channel and originated at what was then Volcano Lake (adjacent to Cerro Prieto). The river flowed northwestward through what is now Mexicali and continued northwestward to a point due south of Superstition Mountain. At this point, it made a $90^{\circ}$ turn and flowed northeastward toward Brawley. These trends in the course of the New River are similar to the tectonic trends in the Salton Trough, suggesting that the New River may reflect deep-seated structures. Although this hypothesis is vague and speculative, it does seem worthy of future consideration.

\section{ConClusions}

A discontinuous zone of ground disturbances occurred along the trend of the New River from Brawley to Wiest Lake during the Imperial Valley earthquake sequence. Although evidence from seismicity suggests that the $M_{L} 5.8$ Brawley earthquake also occurred along this zone, no evidence for primary surface faulting was found along this zone. Even though it may be more than fortuitous that these trends coincide, we found no proof that these disturbances were caused by the Brawley aftershock.

\section{ACKNOWLEDGMENTS}

We thank Carl Johnson, Kerry Sieh, and Clarence Allen for enlightening discussions. Les Youd and John Sims provided useful comments on the manuscript. We also thank Gisela Anderson for helping with the drafting. One of the authors (J. G. A.) was a senior research associate at the Department of Civil 
Engineering, University of Southern California, when this research was initiated, and his research was partially supported by NSF Grant PFR 78-06926.

\section{REFERENCES}

Anderson, J. G. and T. H. Heaton (1982). Aftershocks recorded on a temporary array, U.S. Geol. Surv. Profess. Paper 1254, The Imperial Valley, California, earthquake of 15 October, 1979, 443-451.

Johnson, C. E. and L. K. Hutton (1982). The 15 October, 1979 Imperial Valley, earthquake: a study of aftershocks and prior seismicity, U.S. Geolog. Surv. Profess. Paper 1254, The Imperial Valley, California, earthquake of 15 October, 1979, 59-76.

Sharp, R. V., J. J. Lienkaemper, M. G. Bonilla, D. B. Burke, B. F. Cox, D. G. Herd, D. M. Tiller, D. M. Morton, D. J. Ponti, M. J. Rymer, J. C. Tinsley, J. C. Yount, J. E. Kahle, E. W. Hart, and K. E. Sieh (1982). Surface faulting in the central Imperial Valley, U.S. Geol. Surv. Profess. Paper 1254, The Imperial Valley, California, earthquake of 15 October, 1979, 119-143.

Sykes, G. (1937). The Colorado delta, Carnegie Institute, Washington, D.C., publication 460.

Youd, T. L. and G. F. Wieczorek (1982). Liquefaction and secondary ground failure, U.S. Geol. Surv. Profess. Paper 1254, The Imperial Valley, California, earthquake of 15 October, 1979, 223-246.

U.S. Geological Survey

SEISMOLOGICAL LABORATORY

California Institute of Technology

Pasadena, California 91125 (T.H.H., P.T.G.)

\author{
Institute of Geophysics and Planetary \\ Physics AND \\ Department of Applied Mechanics and \\ Engineering ScIEnce \\ University of California, San Diego \\ La Jolla, California 92093 (J.G.A.)
}

Manuscript received 17 January 1983 